\title{
Social Hygiene Movement and Psychology: Towards Another Paradigm in Mental Health
}

\author{
Rafael Nogueira Furtado, Juliana Aparecida de Oliveira Camilo, George Moraes de Luiz \\ Department of Psychology, Pontifícia Universidade Católica de São Paulo, São Paulo, Brazil \\ Email: rnfurtado@yahoo.com.br
}

How to cite this paper: Furtado, R. N., de Oliveira Camilo, J. A., \& de Luiz, G. M. (2018). Social Hygiene Movement and Psychology: Towards Another Paradigm in Mental Health. Psychology, 9, 934-944. https://doi.org/10.4236/psych.2018.95058

Received: March 20, 2018

Accepted: May 7, 2018

Published: May 10, 2018

Copyright $\odot 2018$ by authors and Scientific Research Publishing Inc. This work is licensed under the Creative Commons Attribution-NonCommercial International License (CC BY-NC 4.0). http://creativecommons.org/licenses/by-nc/4.0/ (c) (i) (8) Open Access

\begin{abstract}
This article discusses the relationships between social hygiene movement and psychology, seeking to present a healthcare paradigm, alternative to hygienism. Social hygiene movement was a popular social movement in Europe and the Americas during the late nineteenth and early twentieth centuries. Its ideas and methods influenced psychology, among many other scientific fields. This influence resulted in social control practices, aimed at the segregation of individuals who did not conform to current social norms. In contrast, at the end of the twentieth century, a paradigm emerges in mental health, called Psychosocial Attention. This paradigm establishes a way of understanding and dealing with mental health, different from that hitherto practiced by the psychology and psychiatry of the time. Thus, this article explains the principles in which Psychosocial Attention is based and the devices idealized for its materialization.
\end{abstract}

\section{Keywords}

Hygienism, Psychology, Psychosocial Attention, Public Health

\section{Introduction}

Psychology consists in a disciplinary field, formed by knowledge and practices that seek to explain and intervene on behaviors, thoughts and emotions. This field emerges from social and historical conditions that determine what is possible to do, to think and to say, in a given epoch. Concurrently, psychology acts on these historical conditions, reinforcing existing social norms, or contributing to the problematization and transformation of these norms.

Among the historical and political conditions from which psychology emerges, we find the social hygiene movement, also called hygienism. Social hygiene movement comprises a set of actions aimed at promoting the health of the 
population and controlling the spread of diseases through interventions in public spaces, human habits and behaviors.

This movement had its apogee, in Europe and the Americas, during the nineteenth and early twentieth centuries, characterized by authoritarian measures of the State, under the pretext of ensuring progress of society. Although it has become prominent in this period, we can find hygienic practices since antiquity, as well as in present days.

The influence of hygienism on psychology led to the development of theories and techniques aimed at the normalization of individuals considered socially deviant. Recent urban interventions, at São Paulo city, Brazil, involving the involuntary hospitalization of substance-dependent people, show us how medical-police actions are not exclusive of the past.

Thus, this article discusses about an alternative paradigm in mental health, capable to overcome practices of subjection that still exist today. Initially, the constitution of the hygienist movement is presented. The article addresses the public health actions, undertaken throughout history, to control disease outbreaks, in order to make population a productive force to the State. Next, the influence of hygienism on psychology is discussed. At the end, this paper presents Brazilian Psychosocial Attention model as a possible alternative to hyginenistic psychology.

\section{Historical Development of Social Hygiene Movement}

The etymological origin of the word hygiene is the ancient Greek term "hygeinos", which means "healthy" (Silva, Paim, \& Schraiber, 2014: p. 4). Since Antiquity and throughout the Middle Ages, we find actions undertaken by rulers over urban space and human conduct, aiming to control diseases and preserve the health of individuals. As an example, we can cite the construction in Rome of Cloaca Maxima (a great sewerage) in the sixth century BC and the medieval practices of isolation of patients to control the Black Death (Straub, 2014).

However, it will be during modernity that the actions of urbanization and management of conduits will become more sophisticated, laying the foundation of the hygiene movement that will arise in the nineteenth century. Two important modern developments preceding the nineteenth century movement are the creation of Political Arithmetic in England, in the seventeenth century, and the creation of the Medical Police in Germany, in the eighteenth century (Silva, Paim, \& Schraiber, 2014).

These two fields of knowledge have, as their main feature, the fusion between health care and the socioeconomic development of a nation. These fields are built on the premise that a healthy population is a productive population, capable of making the nation prosper. Therefore, the State must act to prevent population from becoming ill, but beyond that, it must maximize its health, optimize the biological potential of human groups.

In the wake of the nineteenth century, these measures of disease control and 
health maximization will be strengthened and expanded. The hygienist period begins. For hygienism, medicine serves not only to treat or prevent disease, but also to coordinate social organization. For it, population is the principal capital of a nation, and therefore health authorities must guide rulers on the public administration, legislators on the creation of laws and magistrates on the application of these laws (Silva, Paim, \& Schraiber, 2014).

Hygienic measures were motivated mainly by the process of industrialization and rural exodus, in Europe, since the seventeenth century. Industrialization has aggravated the sanitary conditions of cities. Therefore, in 1842, England, the Chadwick Report is elaborated. It contained an analysis of the health conditions of the working population and proposed ways to improve these conditions (Czeresnia, Maciel, \& Oviedo, 2013).

In Brazil, the hygienist movement has been established since the end of the Empire, following the first Republic and the Vargas Era. The measures taken during this period refer mainly to urban sanitation and epidemic control actions, such as yellow fever, plague and smallpox, through the elimination of vectors and vaccination. The direct link between health and social development is clear in the case of Brazil. The sanitation actions of this period were mainly aimed at sanitizing the ports, so that the epidemics did not threaten agroexportations (Paim, 2009).

Among the characteristics of the hygienist actions are the truculence and the authoritarianism with which they were practiced. As an example, we can mention: 1) the urban reforms carried out in the city of Rio de Janeiro at the beginning of the 20th century and 2) obligatory vaccination against smallpox (Mansanera \& Silva, 2000).

In order to modernize the city and make it more civilized, the mayor of Rio de Janeiro, Pereira Passos, overthrew tenements and destroyed large urban stretches between 1902 and 1906. He forced the poor people who lived in these places, out to peripheral regions, believing that the city would be healthier this way. In the same period, a law was established in the country to ensure the obligatory vaccination of the population against smallpox. For those who refused to receive the vaccine, the State sent sanitary brigades to invaded houses and apply the vaccine by force (Mansanera \& Silva, 2000).

Moreover, among the somber and authoritarian facets of hygienism, we find the movement called eugenics. The term eugenics was coined by the English thinker Francis Galton in the late nineteenth century. According to Galton, there are certain human characteristics that are more desirable than others (such as intelligence). These characteristics are largely hereditary (Kevles, 1998). As a result, he affirmed that two main practices should be undertaken, to improve our society: 1) encouraging reproduction among people with better skills, generating better offspring; and 2) prevent weak and degenerate people to reproduce (Kevles, 1998).

Speaking as the authors of this article, we assure here our position against any kind of eugenic practices. Although eugenics is most commonly associated with 
Nazism, ideas for the improvement of the human species were disseminated in several countries during the early twentieth century. Sterilization and segregation laws were introduced in Switzerland, Denmark, Finland, Mexico, Cuba, the United States, Iceland, Lithuania, Hungary, among others, to prevent the reproduction of such degenerate individuals (Rose, 2013).

\section{Psychology and Social Control}

This whole set of ideas and interventions, here described, will so far influence psychology, which emerges as an autonomous science in 1879 (Weiten, 2016). Traditionally, science has as its pretension to produce a neutral and objective knowledge about the world. However, despite this claim, scientific knowledge reflects moral values, economic and political interests of a society.

Psychology, like other health sciences, operates according to the concept of normality. It is considered normal what conforms to a norm. This norm can be defined in two main ways: 1) norm as being those features most frequently presented in a population (thus, for example, we can say that it is normal for Brazilian adult men to have an average height of 1 meter and $75 \mathrm{~cm}$ ); 2) norm is also defined as an ideal model to be achieved (for example, a human species composed mainly of subjects with high intellectual abilities, as sought by eugenics) (Foucault, 2008).

In seeking to normalize individuals, psychology reinforces current social patterns, often contributing to the reproduction of inequalities, oppression and exclusion relations present in our culture. We can observe this phenomenon more clearly in the way it has dealt with human mental health over time.

The history of madness, as taught by thinkers such as Michel Foucault, reveals to us that psychology, to some extent, reproduced hygienic practices along its history. For Foucault, the pathologization of madness, its definition as mental illness, occurs at the end of the eighteenth century. This pathologization would not result from the discovery of the true nature of madness. It consists in another step in a long journey of social control of madness (Foucault, 2004).

Foucault identifies as one of the milestones of this process of control, the creation of the General Hospital of Paris, in the middle of the seventeenth century. This hospital, as well as other similar institutions created in this period, did not have as main function the medical treatment, but the maintenance of the social order.

These institutions were a legal-police instrument designed to keep locked those individuals whose conduct did not conform to moral norms, such as: insane people, suicidal individuals, witches, homosexuals, wanderers, people with venereal diseases, among others. By means of this great enclosure, a double benefit was obtained: 1) the city was sanitized from deviant individuals; 2) at the same time, these people were subjected to disciplinary regimes, so that they could recover the reason and morals they had lost.

From this social perception of madness, psychiatry will arise and, later, psy- 
chology. According to Foucault, the understanding of madness as a mental illness and its treatment by doctors and psychologists reproduces this place of exclusion and domination in which the madman was situated. Psychiatry emerged at the end of the eighteenth century, with the work of Philippe Pinel, a French physician, who devoted himself to the study and treatment of so-called mental alienation (Foucault, 2004).

Moved by the ideals of French Revolution, Pinel became known for ridding the madmen of the chains in which they were usually kept in hospitals. He established the first psychiatric hospitals, understanding that this institution was the main tool for the treatment of mental alienation. Instead of the chains, treatment proposed by Pinel and the nascent psychiatric science consisted in interning madmen, full-time, in the psychiatric hospital. So that, it was possible to obtain the following benefits: 1) to observe and study mental illness in a natural and uninterrupted setting; 2) overcome madmen's resistance and prepare them for moral treatment, equally avoiding external interference (Foucault, 2004).

Moral treatment consisted in imposing order and discipline on the daily routine of the patient, who should obey rules of conduct, schedules and, in addition, be submitted to physical work. Work would re-educate the unruly mind and emotions of alienated individuals. Psychiatric hospitals have become popular throughout the nineteenth century, many similar institutions were created, including in Brazil. In the 1850s the Dom Pedro II Hospice was established in Rio de Janeiro, the first Brazilian asylum (Paim, 2009).

In turn, psychology, emerging as a science in the late nineteenth century, relies on this conception of madness and adds to the studies of the time, its own theories and techniques. Throughout the twentieth century, various explanatory systems were formulated, such as psychoanalysis, behaviorism, humanism, cognitive psychology, among other approaches.

The process of normalization and social control conducted by psychology was not restricted to the walls of hospitals. It was applied to schools, factories, armies and prisons. By means of psychological knowledge, disciplinary devices were developed, being capable of rendering the subjects docile and obedient, extracting from them their maximum productive force. These devices refer to strategies on how to: organize time, distribute bodies in spaces, perform surveillance and apply punishments.

We can cite as an example of social control exercised by psychology, the massive participation of psychologists in the American army during the first and second World Wars. The function of psychologists in this context was to apply psychological tests to soldiers, in order to direct them to tasks they fitted most.

After the war, these tests continued to be used, but this time in school and clinical settings (Ferreira, 2011). Thus, we observe in psychology, the same feature that characterized hygiene, namely, the belief that population is the principal capital of a nation, therefore, it is necessary to make the population healthy so that individuals can be useful and productive. 


\section{A Paradigm Shift in Mental Health}

Up to this point, paper described the social hygiene movement and its influence on psychology. However, now it is time for envisage ways of overcoming these practices of social control, in the direction of an alternative model of care. Psychosocial Attention can be considered as a paradigm, guiding psychological assistance, opposed to hygienism. Psychosocial Attention is the term that designates current model of mental health practices in Brazilian public health today.

This model was born as a result of the Psychiatric Reform that occurred in the country, which sought to overcome the degrading approach to madness in asylums. Psychiatric Reform was materialized by a bill formulated in 1989, becoming law in 2001: the Law 10.216, known as the Psychiatric Reform Law. This act is the main political instrument that gives legitimacy to the psychosocial actions of prevention, promotion and treatment, in the field of mental health (Brasil, 2001).

But where Psychosocial Attention paradigm differs from hygienism? First, in this new model, a shift from disease to the individual occurs. To traditional psychiatry, the relationship established in medical treatment is between the professional and the illness. The individual who suffers is seen only as a background for the disease. In Psychosocial Attention, the disease is placed in parentheses. The subject occupies the center of health professional care (Amarante, 2013).

Second, as the subject moves to the center of attention, he assumes a leading role that the patients did not know until then. In the traditional model, the madman is one who has lost his reason, and therefore his speech is incoherent, he must be silenced and passively receive the treatment. But, in the critical model, the patient plays an active role in his treatment (Amarante, 2013).

Third, along with these two shifts, we see another change of perspective. Madness is no longer seen as merely the impairment of organic systems. It is a result of the social conditions in which individuals live. Thus, mental health stems from a combination of biological, psychic and social factors. Therefore, mental health care should aim at: 1) both prevention and treatment actions; 2) should be conducted by a multidisciplinary team; and 3) should focus on the reinsertion of the subject in his community, giving preference to outpatient visits and reducing the number of hospitalizations (Amarante, 2013).

Two events were decisive for the promulgation of Psychiatric Reform Law, in 2001: the enactment of the Constitution of 1988 and the elaboration of the Organic Law of Health of 1990. The Constitution defines health (not just mental health) as a citizen's right and a State's duty. It affirms that this obligation of the State shall be guaranteed by: 1) social and economic policies aimed at reducing the risk of disease and other harms; and 2) universal and equal access to services of promotion, protection and recovery of health (Brasil, 1988).

Together with the Organic Law of Health, the Constitution establishes the Unified Health System (SUS - Sistema Único de Saúde) as a way of providing due attention to the health of the citizen. The SUS consists of a network, com- 
posed of different points of attention interconnected, which should be able to complement each other and communicate with each other. According to the legislation, the health care offered by this network should obey SUS doctrinal principles.

The doctrinal principles are: 1) universality, that is, the right of every citizen to have access to public services, regardless of their socioeconomic status, ethnicity or gender; 2) Equality, that is, in addition to universal access to health, everyone should receive the same quality of care; and c) integrality, which implies the right to services, at all levels of complexity (Brasil, 1990).

These political achievements constitute the basis upon which a new model of care for the individuals in mental suffering could be built in Brazil. Psychiatric Reform Law establishes, in its second article, the rights for people with mental disorders.

Among these main rights, we can mention: 1) be treated with humanity and respect; 2) be protected from all forms of abuse and exploitation; 3 ) to achieve recovery through insertion into the family, work and in the community; 4) access to the media; 5) receive clarification about their illness and treatment; 6) and be treated preferably in community services (Brasil, 2001).

In addition the Law determines, to ensuring respect for the dignity of patients, the conditions for their hospitalization. The main terms to which hospitalization is conditioned are: 1) hospitalization will be indicated only when all extrahospital resources are insufficient; 2) the treatment should aim at the social reintegration of the patient; 3) admissions to asylum-like institutions are prohibited (Brasil, 2001).

\section{Psychosocial Attention Network}

As said, mental health care, offered by psychologists and other professionals, in Brazilian public health, occurs through the Unified Health System (Sistema Unico de Saúde - SUS). SUS network of mental health services is, specifically, called Psychosocial Attention Network (Rede de Atenção Psicossocial - RAPS). RAPS consists of seven basic components. Each component refers to a specific set of health actions, which are materialized through Points of Attention. Points of Attention are establishments (such as hospitals, clinics, ambulatories, etc.) in which health actions are conducted (Brasil, 2011).

The seven RAPS components, systematized by Administrative Rule no. 3,088 of December 2011, are: 1) Primary healthcare; 2) Specialized psychosocial care; 3) Urgent and emergency care; 4) Residential care of transitory character; 5) Tertiary healthcare; 6) Deinstitutionalization strategies; and 7) Psychosocial rehabilitation (Brasil, 2011).

Primary healthcare refers to the health actions of low complexity, carried out in the environments population lives, constituting the entrance door for the population to the system. In this component, we find as Points of Attention, for example, the "Primary Healthcare Units", "Consultation Offices in the Street" 
and the "Community Centers".

Primary Healthcare Units develop actions to promote mental health, prevention of mental disorders, harm reduction actions and care for users of alcohol and other drugs, always being articulated to other network points. In turn, regarding those individuals living in the streets, with difficulties to access primary units, Consultation Offices in the Street were created.

They are traveling multiprofessional teams that go to this population, aiming to carry out preventive actions, health promotion, harm reduction actions, diagnoses and referrals. RAPS also has Community Centers. They refer to spaces of sociability offered to the general population, where art workshops, cultural events, recreational activities are developed, dedicated to the social reinsertion of patients (Brasil, 2011).

With regard to the second RAPS component, Specialized Psychosocial Care, it designates actions focused on mental health problems of medium and high complexity. While basic care focuses on prevention and health promotion measures, specialized care consists in treatment actions performed by specialist professionals.

Points of Attention for these actions are the so-called "Psychosocial Attention Centers" (Centros de Atenção Psicossocial - CAPS). They count on multiprofessional teams, in charge of the diagnosis, treatment and rehabilitation of patients with mental disorders, through psychotherapies, therapeutic workshops, prescription of medications, among other measures.

There are several types of CAPS currently in operation: CAPS I, suitable for municipalities with more than 15 thousand inhabitants; the CAPS II, for municipalities with more than 70 thousand inhabitants; the CAPS III, which operates seven days a week, 24 hours a day and with extended staff. In addition, there are modalities of CAPS aimed at specific publics, such as CAPS AD (for users of alcohol and other drugs) and CAPS i, specialized in children and adolescents care (Brasil, 2011).

The third component of RAPS, refers to Urgent and Emergency Care. It implies actions aimed at the rapid evaluation and management of crises, carried out through various services and establishments, such as: ambulances which conduct emergency assistance; Emergency rooms; Primary healthcare units; CAPS. In these contexts, for example, risk classification strategies are used. According to them, the flow of care is organized, prioritizing cases of greater severity (Brasil, 2011).

The fourth component of the network consists of Residential Attention of Transitory Character. This set of actions is born within the policies to confronting cocaine-crack consumption, aiming to shelter individuals in living in streets or whose family environment is cause of aggravation of their health.

In this component, we find two main Points of Attention. The first of these are the "Shelter Units". These are residences in operation 24 hours a day, in which are carried out therapeutic and protective assistance, for a maximum period of 6 months. Shelter Units are organized in two ways: those for adults, users 
of crack, alcohol and other drugs; and those aimed at children and adolescents, aged between 10 and 18 years.

The second Point of Attention refers to "Therapeutic Communities". These services provide continuous health care for a maximum period of 9 months. All these Points of Attention should work in conjunction with CAPS and with the primary care services (Brasil, 2011).

The Psychosocial Care Network (RAPS) also has devices capable of dealing with situations of high complexity, which require the hospitalization of the individual. The fifth component, Hospital Attention, brings together actions carried out in "General Hospitals", in the "Centers of Integrated Attention to Mental Health" (CAISM) and in the "Psychiatric Hospitals", still existing in the country.

As we have seen, a central aspect of the Psychiatric Reform was the fight against the hospitalization of mentally ill patients. The Law of 2001, which regulates this reform, does not determine the elimination of psychiatric hospitals, but of institutions with asylum characteristics. However, this is a topic in constant discussion (Brasil, 2011). As the authors of this article, we agree with the condemnation of asylum institutions, acknowledging the relative importance of brief hospitalization for managing acute psychiatric crises.

There are authors who criticize the reduction of beds for psychiatric inpatients, which has been occurring since the enactment of the Law. On the other hand, other authors believe that this reduction is beneficial, and the government should focus its policies on strengthening alternative services, such as CAPS and the therapeutic residences (Amarante, 2003).

Hospital Attention is closely linked to the sixth component of RAPS, called Deinstitutionalization Strategies. These are initiatives which seek to provide care, outside the hospital institution, to people in long-term hospitalization, encouraging their institutional egress. The "Residential Therapeutic Services" are the Point of Attention of this component. They consist of houses designed to accommodate people who are long-term hospital residents (i.e., two years or more, uninterrupted). The "Homecoming Program" (Programa De Volta para Casa) is a policy aimed at stimulating this social reintegration (Brasil, 2011).

Finally, the last component of RAPS refers to Social Rehabilitation. It is comprised of initiatives to generate work and income for patients, through enterprises of solidarity economy and social cooperatives (Brasil, 2011).

\section{Final Considerations}

This paper presented the characteristics of Psychosocial Attention as a paradigm for Psychology. It has as its main contribution, the discussion about challenges in public health, addressing forms of assistance alternative to social hygiene movement.

Psychosocial Attention is a field of knowledge and practices, designating a model of care for individuals and collectives, which differs from hygienism. The latter consists in authoritarian social measures, aimed to control people's beha- 
vior by means of violence, segregation and expropriation. In contrast, Psychosocial Attention seeks to reinsert patients in the community, counting on multiprofessional teams and a network of establishments. It proposes actions in all levels of complexity, in order to attain prevention and treatment of diseases, as well as the promotion of health.

However, the theoretical proposals of the model do not always result in concrete actions in Brazilian public healthcare system. There is an evident gap between the principles of Psychosocial Attention and reality. Crises affecting Brazilian government directly harm the population who lean on this system. There are problems of management, financing and professional qualification that prevent the provision of decent care. Thus, we must continue to fight for the Psychiatric Reform, since it has not yet been fully accomplished. Only this way, can we finally overcome the hygienic practices that injure society.

\section{References}

Amarante, P. (2003). Saúde mental e atenção psicossocial. Rio de Janeiro: Fiocruz.

Brasil (1988). Constituição da República Federativa do Brasil de 1988. http://www.planalto.gov.br/ccivil_03/constituicao/constituicao.htm

Brasil (1990). Lei no 8.080 de 19 de setembro de 1990. http://www.planalto.gov.br/ccivil_03/leis/18080.htm

Brasil (2001). Lei no 10.216 de 6 de abril de 2001. http://www.planalto.gov.br/ccivil_03/leis/leis_2001/110216.htm

Brasil (2011). Portaria no 3.088 de 23 de dezembro de 2011. http://bvsms.saude.gov.br/bvs/saudelegis/gm/2011/prt3088_23_12_2011_rep.html

Czeresnia, D., Maciel, E. M., \& Oviedo, R. A. (2013). Os sentidos da saúde e da doença. Rio de Janeiro: Fiocruz. https://doi.org/10.7476/9788575415269

Ferreira, M. (2011). Breve história da moderna psicologia social. In C. Torres \& E. R. Neiva (Eds.), Psicologia social: Principais temas e vertentes (pp. 10-22). Porto Alegre: Artmed.

Foucault, M. (2004). História da loucura na idade clássica (7. ed.). Rio de Janeiro: Perspectiva.

Foucault, M. (2008). Segurança, território, população. São Paulo: Martins Fontes.

Kevles, D. (1998). In the Name of Eugenics: Genetics and the Uses of Human Heredity. Cambridge, MT: Harvard University Press.

Mansanera, A. R., \& Silva, L. C. (2000). A influência das ideias higienistas no desenvolvimento da psicologia no Brasil. Psicologia em estudo, 5, 115-137.

http://www.scielo.br/scielo.php?pid=S141373722000000100008\&script=sci_abstract\&tl $\underline{\mathrm{ng}}=\mathrm{pt}$

https://doi.org/10.1590/S1413-73722000000100008

Paim, J. (2009). O que é o SUS? Rio de Janeiro: Fiocruz.

Rose, N. (2013). A política da própria vida: Biomedicina, poder e subjetividade no século XXI. São Paulo: Paulus.

Silva, L., Paim, J. S., \& Schraiber, L. (2014). O que é saúde coletiva? In J. S. Paim, \& N. Almeida-Filho (Eds.), Saúde coletiva: Teoria e prática (pp. 3-12). Rio de Janeiro: Medbook. 
R. N. Furtado et al.

Straub, R. O. (2014). Psicologia da saúde: Uma abordagem biopsicossocial (3 ed.). Porto Alegre: Artmed.

Weiten, W. (2016). Introdução à psicologia: Temas e variações (3 ed.). São Paulo: Cengage Learning. 